Inflammation, Vol. 16, No. 5, 1992

\title{
SYNERGISM AMONG OXIDANTS, PROTEINASES, PHOSPHOLIPASES, MICROBIAL HEMOLYSINS, CATIONIC PROTEINS, AND CYTOKINES
}

\author{
I. GINSBURG, ${ }^{1}$ R. MISGAV, ${ }^{1}$ A. PINSON,${ }^{3}$ J. VARANI, ${ }^{4}$ \\ P. A. WARD ${ }^{4}$ and R. KOHEN ${ }^{2}$ \\ ${ }^{1}$ Department of Oral Biology \\ Hebrew L'niversity-Hadassah School of Dental Medicine \\ ${ }^{2}$ Department of Pharmacy \\ Hebrew University-Hadassah School of Pharmacy \\ ${ }^{3}$ Laboratory for Myocardial Research \\ Hebrew University-Hadassah School of Medicine \\ Jerusalem, Israel \\ ${ }^{4}$ Department of Pathology \\ University of Michigan School of Medicine \\ Ann Arbor, Michigan
}

\begin{abstract}
A striking similarity exists between the pathogenetic properties of group A streptococci and those of activated mammalian professional phagocytes (neutrophils, macrophages). Both types of cells are endowed by the ability to adhere to target cells; to elaborate oxidants, hydrolases, and membrane-active agents (hemolysins, phospholipases); and to freely invade tissues and destroy cells. From the evolutionary point of vew, streptococci might justifiably be considered the forefathers of "modern" leukocyles. Our earlier findings that synergy between a streptococcal hemolysin (streptolysin S, SLS) and a streptococcal thiol-dependent proteinase and between cytotoxic antibodies + complement and streptokinase-activated plasmin readily killed tumor cells, led us to hypothesize that by analogy to the pathogenetic mechanisms of streptococci, the mechanisms of tissue destruction initiated by activated leukocytes in inflammatory sites, as well as in tissues undergoing episodes of ischemia and reperfusion, might also be the result of the synergistic effects among leukocyte-derived oxidants, phospholipases, proteinases, cytokines, and cationic proteins. The current report extends our previous synergy studies with endothelial cells to two additional cell types-monkey kidney epithelial cells and rat beating heart cells. Monolayers of ${ }^{51} \mathrm{Cr}$-labeled cells that had been treated by combinations of sublytic amounts of hydrogen peroxide (generated either by glucose oxidase, xan-
\end{abstract}


thine-xanthine oxidase, or by paraquat) and with sublytic amounts of a variety of membrane-active agents (streptolysin $\mathrm{S}$, phospholipases $\mathrm{A}_{2}$ and $\mathrm{C}$, lysophosphatides, histone, chlorhexidine) were killed in a synergistic manner (double synergy). Crystalline trypsin markedly enhanced cell killing by combinations of oxidant and the membrane-active agents (triple synergy). Injury to the cells was characterized by the appearance of large membrane blebs that detached from the cells and floated freely in the media, looking like lipid droplets. Cytotoxicity induced by the various combinations of agonists was depressed, to a large extent, by scavengers of hydrogen peroxide (catalase, dimethyl thiourea, and by $\mathrm{Mn}^{2+}$ ) but not by SOD or by deferoxamine. When cationic agents were employed together with hydrogen peroxide, polyanions (heparin, polyanethole sulfonate) were also found to inhibit cell killing. It is proposed that in order to effectively combat the deleterious toxic effects of leukocyte-derived agonists on cells and tissues, antagonistic "cocktails" comprised of cationized catalase, cationized SOD, dimethylthiourea, $\mathrm{Mn}^{2+}+$ glycine, proteinase inhibitors, putative inhibitors of phospholipases, and polyanions might be concocted. The current literature on synergistic phenomena pertaining to mechanisms of cell and tissue injury in inflammation is selectively reviewed.

\section{INTRODUCTION}

A voluminous literature exists on the role played by microbial toxins (1-4), their enzymes (5), and cell-wall components $(6,7)$ as well as by complement components (8), activated leukocytes, their hydrolases, oxygen radicals, cationic proteins, and cytokines (9-16) in the pathogenesis of infectious and inflammatory diseases. Because of the great complexity of the biochemical, pharmacological, immunological, and pathological processes that are involved in inflammation, there is a tendency to investigate, in depth, the pathogenetic role played by one single agonist at a time, rather than develop models that analyze the effects of multiple factors in the initiation of tissue damage. This approach is probably justified since the construction of complex models might be fraught with many technical and interpretational difficulties.

To shed more light on this important issue, it might be relevant to analyze the experimental models that have been employed to elucidate the pathways of pathogenesis of group A streptococcal infections $(17,18)$ as these might shed more light on the pathobiology of inflammation.

Group A streptococci are catalase-negative, hydrogen peroxide-producing microorganisms that are endowed with the ability to spread in tissues due to the action of potent hydrolases (hyaluronidase, four DNase isozymes, ribonuclease, a lipoproteinase, NADase, acid phosphatase, $\mathrm{N}$-acetylglucosaminidase, an SHdependent proteinase, streptokinase, which activates plasminogen to plasmin, neuraminidase, and numerous still-unidentified antigens with pathogenetic potential) $(17,18)$. A C5a-inactivating enzyme generated by this microorganism might affect neutrophil accumulation at sites of infection (19).

Furthermore, streptococci synthesize two potent cardiotoxic cytolysins, streptolysins $\mathrm{O}$ (SLO) and S (SLS), and an erythrogenic toxin with pyrogenic, 
mitogenic, immune-modulating, and cytotoxic properties (17, 20-24). Streptococci also possess a membrane-associated, amphipathic, lipoteichoic acid (LTA) (25) that facilitates adherence to cell surfaces (26) and the delivery of a variety of metabolites, including hydrogen peroxide, proteinases, as well as of the cellbound SLS, which migh: all act, in concert, to kill cells $(20,23,27)$. LTA also stimulates the generation of TNF (28) and activates complement (29). Therefore, streptococci bear a striking similarity to activated neutrophils or macrophages, which are also capable of adhering to cell surfaces $(30,31)$, of elaborating and delivering upon targets numerous hydrolases, phospholipases, oxidants, cytokines, and arachidonic acid metabolites, all of which might act in concert to kill cells and destroy tissues. Both PMNs and macrophages also freely migrate into and spread in tissues.

Our studies on the mechanisms of cell and tissue injury induced by group A streptococci (17) showed that synergy between a streptococcal hemolysin (streptolysin S, SLS) and a thiol-dependent proteinase (32); among cytotoxic antibodies, complement, and streptokinase-activated plasmin (33); and among LTA-anti-LTA antibodies and complement $(34,35)$, killed mammalian cells in vitro. These findings lec. us to hypothesize that, by analogy to the streptococcal models, the mechanisms of cell and tissue injury induced in inflammatory processes might perhaps also be the result of multiple synergistic interactions among leukocyte agents (oxidants, hydrolases, including phospholipases, cationic proteins, and serum factors). This assumption is further supported by a series of investigations showing that synergy between cationic bactericidal peptides and hydrogen peroxide was also highly cytocidal for mammalian cells (36-39). Furthermore, combinations of hydrogen peroxide, cationic polypeptides, phospholipases, microbial hemolysins, and proteinases killed endothelial cells (40) and epithelial cells (43), in a synergistic manner and also released large amounts of arachidonic acid metabclites from endothelial cells (42). Combinations between oxidants and a variety of proteinases (elastase, neutral proteinases) also killed target cells in a synergistic manner (43-45) and enhanced lung injury due to oxidants (43). We have also shown (46) that synergy among cationic polypeptides, calcium ionophore, chemotactic factors, and lectins led to the generation of enhanced amounts of superoxide, hydrogen peroxide, and chemiluminescence by human neutrophils and suggested that the excessive generation of oxidants, under similar conditions, might represent models of tissue damage. Other studies have shown that neutrophils and macrophages "primed" either by chemotactic peptides (47), LPS (48), lysophosphatides $(49,50)$, or by LTA (51) generated synergistic amounts of hydrogen peroxide. In addition to the studies described above, an extensive literature exists on the role played by well-defined oxidants on cells and tissues in both in vitro and in vivo models. Only selected recent papers are quoted $(9,11-14,52-60)$.

There is also an increasing interest in the role played by oxidants as the 
main agonists responsible for inducing tissue damage following ischemia and reperfusion of various organs $(61,62)$. A review of the clinical and experimental data on this subject (61-65) strongly suggests that, by analogy to the in vitro synergy, models described above, cooperation among oxidants, phospholipases, proteinases, cationic proteins, and a variety of other agonists derived from activated leukocytes might also contribute to extensive tissue damage seen following ischemia and reperfusion episodes affecting a multiplicity of organs.

The present communication further examines synergy among oxidants, proteinases, cationic proteins, a streptococcal hemolysin, and phospholipases in the killing of monkey kidney epithelial cells and beating rat heart cells in culture. The possibility of using "cocktails" comprised of antioxidants, inhibitors of proteinases and phospholipases, as well as of polyanions, to combat the deleterious effects of the agonists generated during the inflammatory process will be briefly discussed.

\section{MATERIALS AND METHODS}

Culture Cells. Neonatal rat heart cultures were prepared as previously described (66). Monkey kidney epithelial cells (BGM) were kindly supplied by Dr. Z. Ronnes of the Department of Virology, Hebrew University School of Medicine. The heart cells were cultivated in Ham F-10 medium supplemented with $10 \%$ bovine serum and $10 \%$ horse serum. The epithelial cells were grown in D-MEM medium supplemented with glutamine, penicillin, and streptomycin and $10 \%$ fetal calf serum (45). Radiolabeled cell monolayers were prepared by the addition of $10 \mu \mathrm{Ci} / \mathrm{ml}$ of $\left[{ }^{51} \mathrm{Cr}\right] \mathrm{NaCrO}_{4}$ (New England Nuclear) to trypsinized cells grown in $75-\mathrm{ml}$ tissue culture bottles. The cells were then dispensed into 24-well tissue culture plates (Nunc, Roskilde, Denmark) and grown to confluency in $\mathrm{CO}_{2}$ incubator.

Reagents. Hydrogen peroxide flux was generated by the addition of various amounts of glucose oxidase $(0.1-0.5$ units $/ \mathrm{ml})$ to the tissue culture media. Hydrogen peroxide was also generated either by a mixture of xanthine $(5 \mathrm{mM})$ and xanthine oxidase $(0.066 / \mathrm{ml})$ or by the addition of paraquat $(1-10 \mathrm{mM})(67)$ to the different media. The amount of superoxide generated was measured by the SOD-inhibitable cytochrome $c$ reduction assay (68). Hydrogen peroxide was assayed by the method of Thurman et al. (69). Streptolysin S (SLS) of group A streptococci (10-100 hemolytic units $/ \mathrm{ml}$ ) (19), phospholipase $\mathrm{C}$ from Clostridium welchii $(0.005-2.5$ units $/ \mathrm{ml})$, phospholipase $\mathrm{A}_{2}\left(\mathrm{PLA}_{2}\right)$ either from bee venom (1-10 units/ml) or from Naja naja (1-20 units $/ \mathrm{ml}$ ) were employed as membrane-damaging agents.

The streptococcal hemolysin and the phospholipases were also assayed by their ability to hemolyze red blood cells as described (22-24). To express the hemolytic and cytolytic activities of $\mathrm{PLA}_{2}, 5 \mathrm{mg} / \mathrm{ml}$ of fatty acid-free albumin was added to the cultures $15 \mathrm{~min}$ after the addition of $\mathrm{PLA}_{2}$. The fatty acids bound the enzymatically cleaved fatty acid and allowed the expression of the OD (3000 units $/ \mathrm{mg}$ ), soybean trypsin inhibitor (10,000 BAEE units $/ \mathrm{mg}$ ), dimethylthiourea (DMTU), $\mathrm{MnCl}_{2}$, heparin, paraquat, and trypan blue (streptolysin S inhibitor) (22-24). All the reagents were purchased from Sigma Israel, Jerusalem, Israel.

Chromium Release Assay. Culture monolayers were treated for different time intervals either with single agents or with combinations among the various agents listed above. The cultures were monitored periodically for changes in cell morphology. To assess cytotoxicity, the supernatant fluids 
were removed and centrifuged at $2000 \mathrm{rpm}$ for $2 \mathrm{~min}$ in Adams Sero-Fuge to eliminate detached cells (45). The solubilized radioactivity was then determined in a Contron gamma counter. The total radioactivity associated with untreated controls was solubilized by the addition of $1 \mathrm{ml}$ of $1 \%$ Triton X-100. The net percentage release of radioactivity in the assay wells was determined by subtracting the radioactivity present in the supernatant fluids of the untreated controls. Cytotoxicity was also assayed by determining the release of lactic dehydrogenase (68).

\section{RESULTS}

Combined Effects of $\mathrm{H}_{2} \mathrm{O}_{2}, \mathrm{SLS}$, and Trypsin on BGM Cells. Figure 1 shows that radiolabeled BGM cells exposed for $2 \mathrm{~h}$ at $37^{\circ} \mathrm{C}$ to a flux of hydrogen peroxide lost only $1.0 \%$ of the chromium label. Similarly, exposure of the cells to increasing concentrations of SLS (10-100 units/ml) did not give rise either to visible cytopathic changes or to a leak of chromium from the cells. The morphological patterns of control untreated cells (Figure 2) and of cells treated with glucose oxidase (GO), which only showed some cell rounding (Figure 3), support the data presented in Figure 1. On the other hand, the simultaneous presence of hydrogen peroxide and SLS resulted in a distinct synergistic chromium release (Figure 1). The most striking morphological changes occurred when SLS was combined with hydrogen peroxide, where cell swelling and the appearance of hyaline blebs, usually in one pole of the cell, took place (Figure 4). These increased in size, with time of incubation, and finally detached from

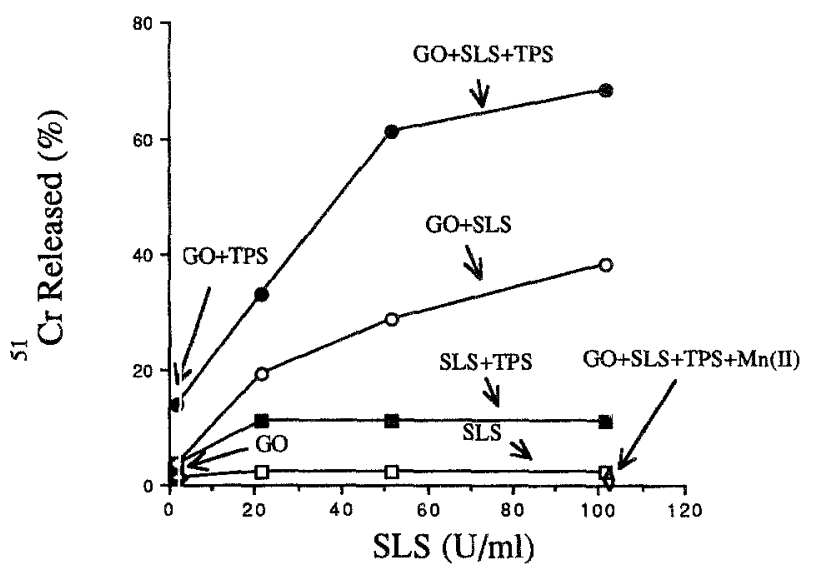

Fig. 1. Effect of streptolysin S (SLS) and glucose oxidase (GO) $(0.5$ units $/ \mathrm{ml})$-generated hydrogen peroxide and crystalline trypsin (TPS) $(25 \mu \mathrm{g} / \mathrm{ml})$ on the killing (chromium release) of BGM cells. Note the synergistic chromiun release induced by combinations among the various reactants. $\mathrm{Mn}^{2+}$ $(1 \mathrm{mM})$ totally inhibited the siynergistic killing of the cells. The data are the average of 10 different experiments. 


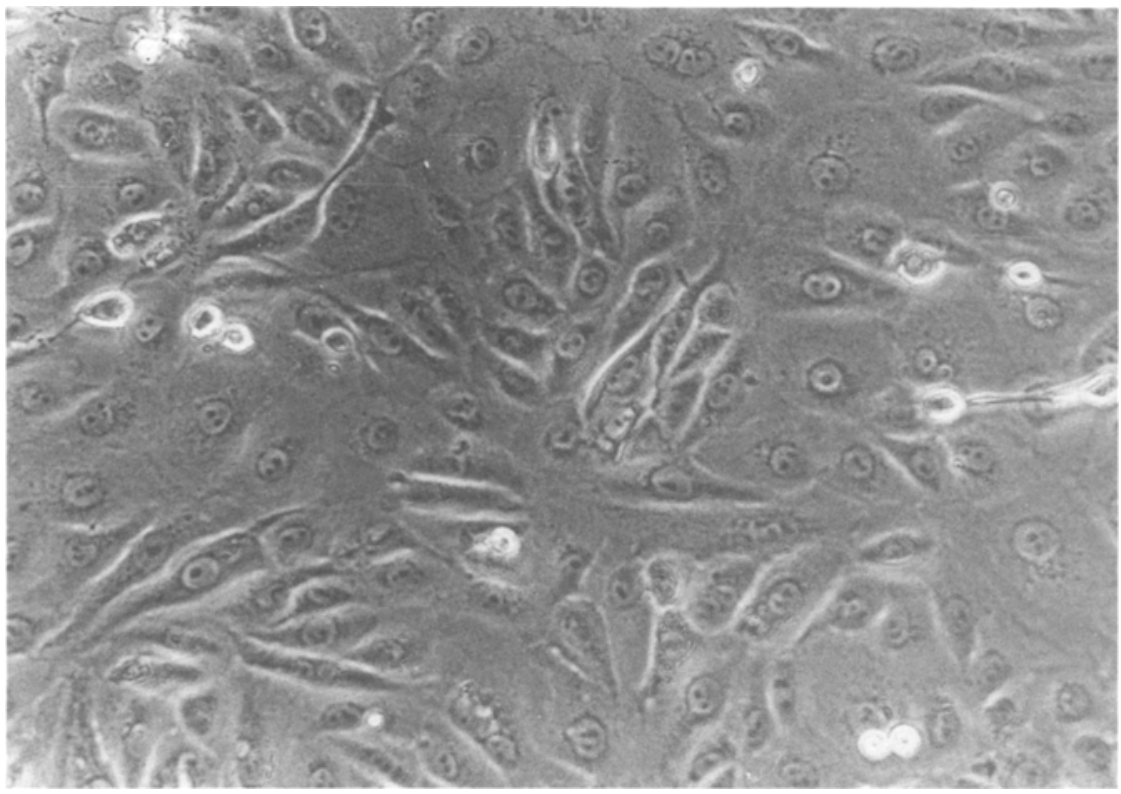

Fig. 2. BGM cells incubated for $90 \mathrm{~min}$ in DMEM medium $(\times 250)$.

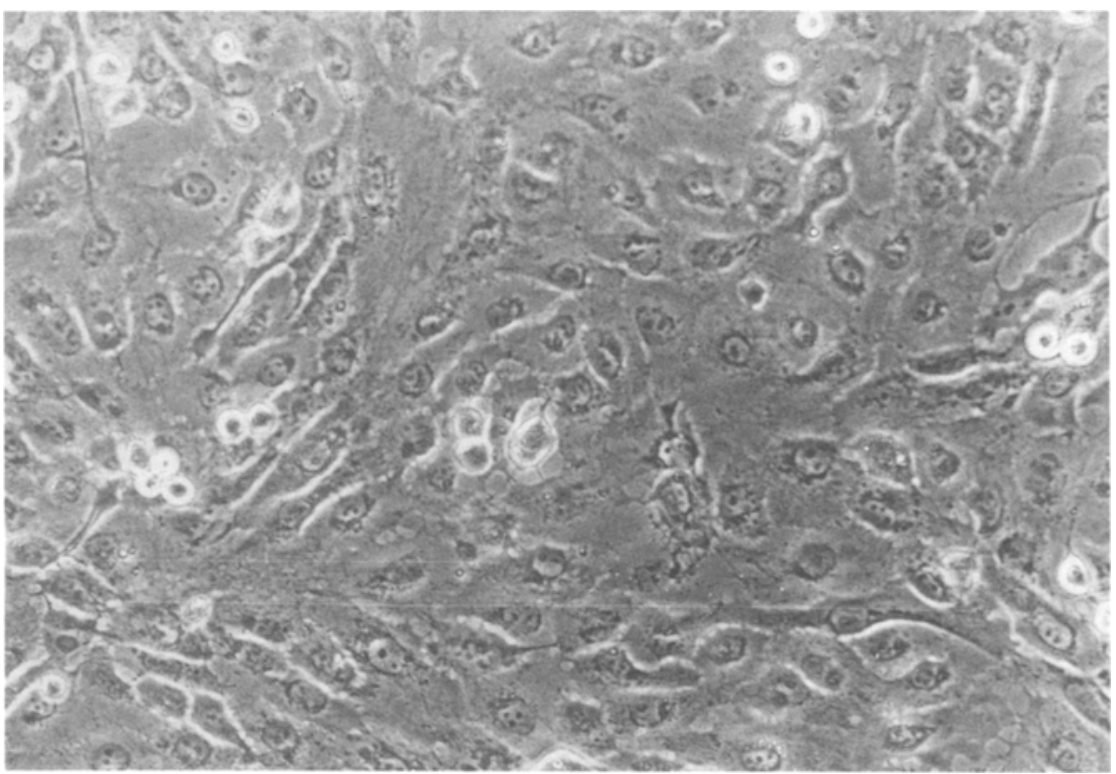

Fig. 3. BGM cells incubated for $90 \mathrm{~min}$ with $\mathrm{GO}(0.5$ units $/ \mathrm{ml})(\times 250)$. 


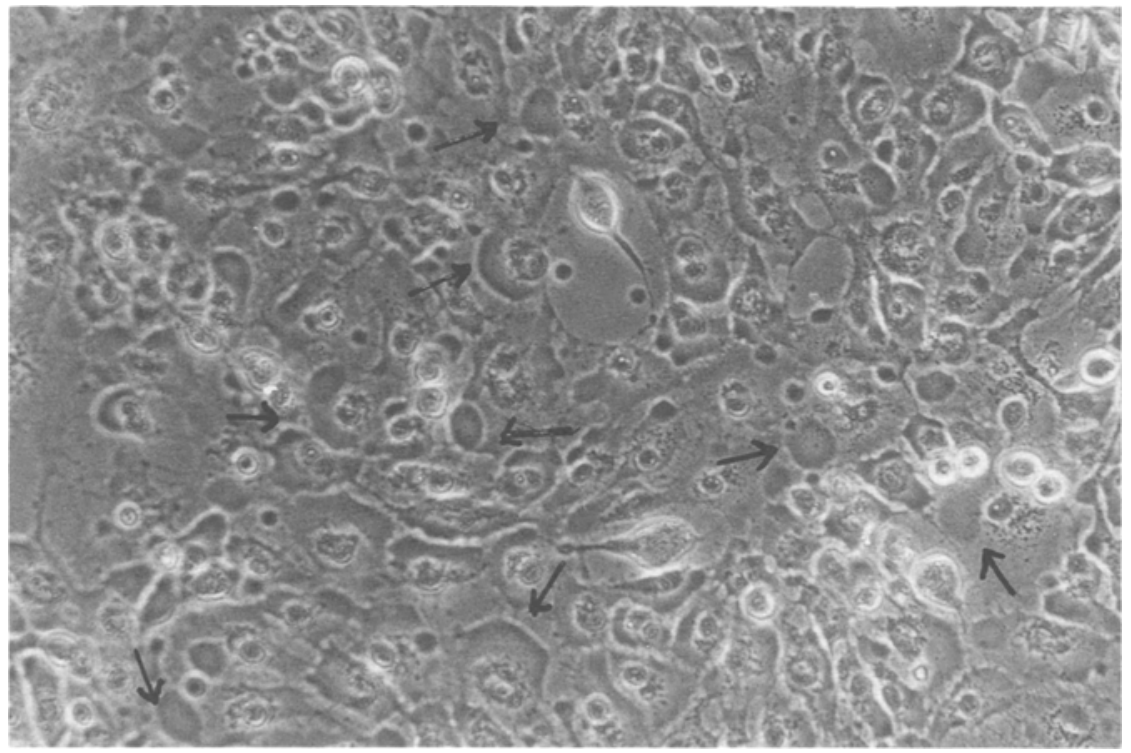

Fig. 4. BGM cells incubated for 90 min with mixtures of SLS ( 100 units $/ \mathrm{ml})$ and GO $(0.5$ units $/$ $\mathrm{ml}$ ). Note the presence of large blebs (pseudopodlike structures) in one pole of the cells and the detachment of lipidlike droplets, representing membrane damage $(\times 250)$.

the cells, forming numerous liposome-like structures that floated freely in the tissue culture media. These distinct cytopathogenic changes were essentially similar to those found by us when rat beating heart cultures were exposed to very large amounts $(1000$ hemolytic units $/ \mathrm{ml})$ of the cell-bound form of streptolysin S (23). Chromium release induced by mixtures of hydrogen peroxide and SLS was totally inhibited either by hydrogen peroxide scavengers [catalase, $\mathrm{Mn}^{2+}$ (70), DMTU (71)] or by trypan blue (a strong inhibitor of SLS) (27). Since proteinases were found to markedly enhance tumor cell killing when streptolysin S was also present $(32,45)$, we tested the combined effects of SLS, hydrogen peroxide, and trypsin on BGM cells. Figure 1 also shows that while trypsin alone (not shown), mixtures of trypsin and SLS, or mixtures of trypsin and hydrogen peroxide, at the concentration tested, were only slightly cytotoxic, the simultaneous presence of all three reagents induced distinct synergistic cell killing as expressed by the very high percentage of chromium released. The exposure of the monolayers to trypsin alone caused cell monolayer shrinkage but no cytopathic changes were obvious (Figure 5). The simultaneous presence of catalase, trypan blue, and SBTI totally inhibited the synergistic cell killing. BGM cells treated by mixtures of GO, SLS, and trypsin were detached from the plate surfaces alreacly at the early stages of incubation, presumably due to 


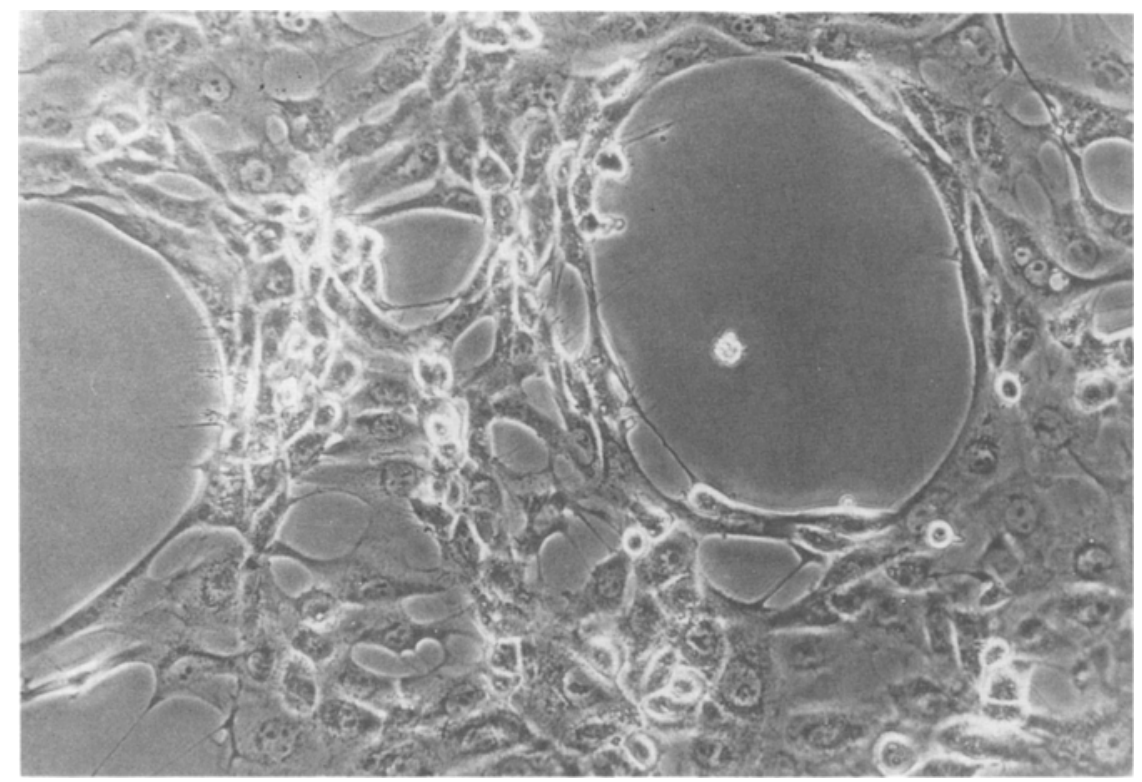

Fig. 5. BGM cells incubated for $90 \mathrm{~min}$ with trypsin $(25 \mu \mathrm{g} / \mathrm{ml})$. Note shrinking of the culture monolayer, but no cytopathic changes are seen $(\times 250)$.

proteinase activity (72). The detached cells were then found to undergo several stages of disintegration (Figure 6). The altered cellular morphology was essentially similar to that previously found with tumor cells (32). Under similar experimental conditions, a synergistic release of chromium from the cells also took place when sublytic concentrations either of histone, chlorhexidine (a cationic antiseptic) PLC, PLA 2 , or lysophosphatides were combined with sublytic amounts of hydrogen peroxide and with crystalline trypsin (not shown). In all cases, cytotoxicity was markedly depressed by hydrogen peroxide scavengers (catalase, DMTU, $\mathrm{Mn}^{2+}$ ) but not by SOD.

Similar synergistic killing of BGM cells also took place when an additional source of an oxidant, xanthine-xanthine oxidase, was combined with SLS (Figure 7A). The combined effect of PLC and GO on BGM cells is also shown (Figure 7B). Synergistic killing of BGM cells also took place when mixtures of paraquat and SLS were employed (Figure 8). Paraquat is known to generate superoxide (67), which dismutates to hydrogen peroxide.

Since mammalian cells are able to repair minor cellular damage that is induced by various noxious agents (73-75) and since cell repair depends on active cell metabolism, we also tested the possibility that glucose-starved cells might become more susceptible to the synergistic effects of oxidants and membrane-active agents. BGM cells were preincubated for $4 \mathrm{~h}$ with $5 \mathrm{mg} / \mathrm{ml}$ of 


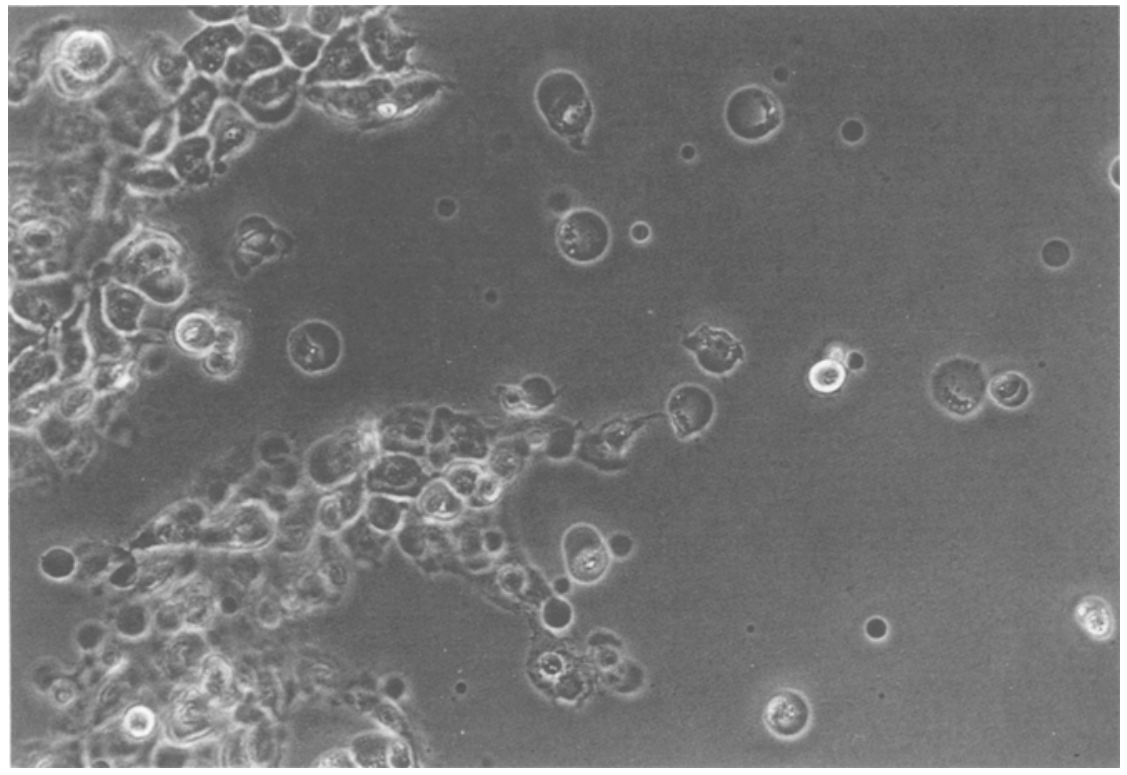

Fig. 6. BGM cells incubated for 90 min with a mixture of SLS ( 50 units $/ \mathrm{ml})$, GO $(0.5$ units $/ \mathrm{ml})$, and trypsin $(25 \mu \mathrm{g} / \mathrm{ml})$. Note destruction the culture monolayer and the accumulation of cell ghosts $(\times 250)$.

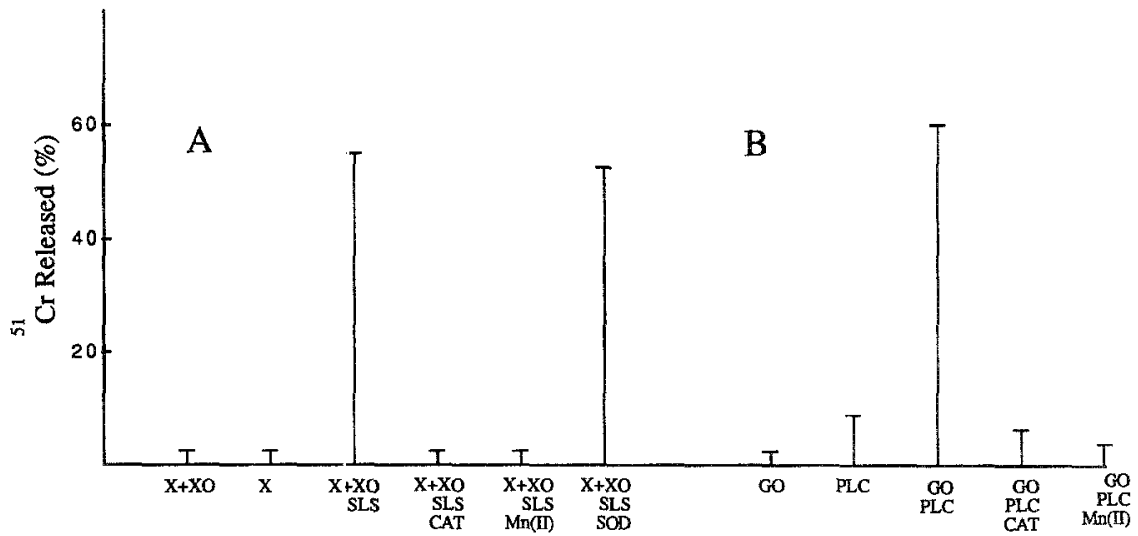

Fig. 7. (A) The combined sffect of xanthine $(5 \mathrm{mM})+$ xanthine oxidase $(0.06$ units $/ \mathrm{ml})$ and streptolysin S (SLS) (50 unils/ml) on chromium release from BGM cells. Note that while SOD failed to inhibit cell killing, $\mathrm{Mn}^{2+}$ at $1 \mathrm{mM}$ totally depressed cell killing. The data are the average of three experiments. (B) The combined effect of GO-generated hydrogen peroxide and phospholipase C $(0.5$ units $/ \mathrm{ml})$ on the killing of BGM cells. Note the distinct synergistic effect between the two agents and the inhibition of cell killing either by catalase or by $\mathrm{Mn}^{2+}$. The data are average of two experiments. 


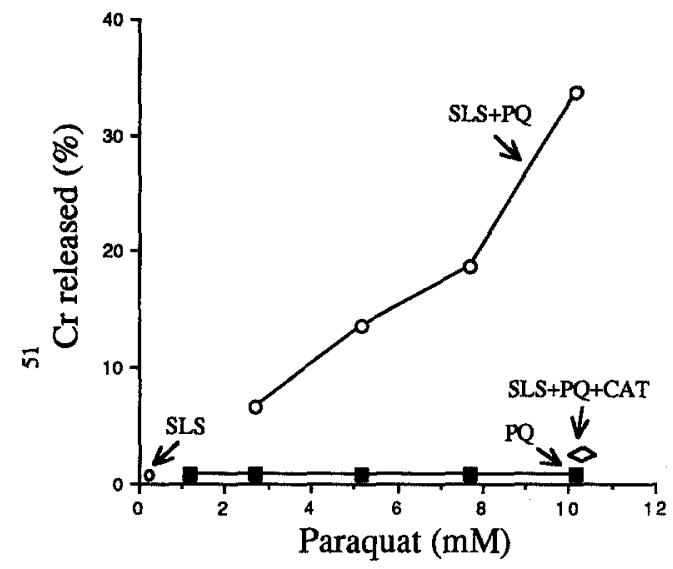

Fig. 8. The combined effect of paraquat and SLS on BGM cells. Increasing concentrations of paraquat were combined with SLS (50 units $/ \mathrm{ml}$ ) and incubated for $90 \mathrm{~min}$. Note the synergistic chromium release by this combination and the inhibition by catalase of cell killing. The data are average of three experiments.

6-deoxyglucose. The monolayers were then exposed either to mixtures of hydrogen peroxide and SLS or to PLC and $\mathrm{H}_{2} \mathrm{O}_{2}$. It was found that whereas glucosestarved cells did not become more susceptible to killing by hydrogen peroxide alone, such cells were killed in a synergistic manner when challenged by mixtures of hydrogen peroxide and the membrane-active agents PLC or SLS. These results are similar to those described previously for deoxyglucose- or puromycintreated endothelial cells (42).

The role of the endogenous antioxidant, catalase, in cellular defense against the synergistic effects of hydrogen peroxide and membrane-active agents (SLS, PLC) was also tested by pretreating the cells either with sodium azide or with aminotriazol (potent catalase inhibitors). Such cells became very susceptible not only to the effect of hydrogen peroxide alone but mainly to the synergistic effects between hydrogen peroxide and the membrane-active agents (not shown). These results are similar to those described by us, showing that azide-treated fibrosarcoma cells became highly susceptible to killing by activated neutrophils (72). These experiments suggest, therefore, that synergistic cell killing by oxidants and membrane-active agents is not restricted to endothelial cells (40-42).

Experiments with Rat Beating Heart Cells. Under similar experimental conditions, beating heart cells exposed to subtoxic concentrations of hydrogen peroxide were also killed in a synergistic manner by the addition of sublytic concentrations of SLS, PLC, histone, or chlorhexidine. As in the case of the BGM cells, putative inhibitors of hydrogen peroxide (catalase, DMTU, and $\mathrm{Mn}^{2+}$ ) totally depressed the synergistic cell killing. The morphological changes induced in the heart cells by the mixtures of oxidants and membrane-active 
agents were similar to those induced in BGM cells showing the development of blebs $(23,77)$, in which cessation of beating appeared much earlier than chromium release.

\section{DISCUSSION}

The data presented further support our previous observations with endothelial cells and show that two additional cell types (epithelial cells and heart cells) can be killed, in a synergistic manner, if treated simultaneously by oxidants and by membrane-active agents. This model system mimics, to some extent, that which employed endothelial or epithelial cells and activated human neutrophils as reported by many investigators (reviewed in 55 and 59). Our most significant observation was the synergy among hydrogen peroxide, a membraneactive agent like SLS, and a proteinase (Figures 1, 4, and 6). Proteinases can presumably enhance the digestion of oxidant-damaged or denatured membrane components. The role played by mixtures of oxidants and proteinases in cellular destruction has been adclressed by several investigators $(43-45,55)$. It has also been suggested that oxidants released from activated leukocytes might destroy proteinase inhibitors and thus facilitate depolymerization of protein structures upon cells (55).

To evaluate the role played by multiple synergistic effects among various agonists, an appraisal should be made of the mechanisms by which each individual component of the cocktail is capable, under set conditions, to injure cells.

The biochemical changes that take place in cells exposed to hydrogen peroxide alone were reviewed (73-75). The interaction of mammalian cells with hydrogen peroxide was found to cause activation of the hexose monophosphate shunt, indicating increased glutathione cycle activity. The DNA strand breaks initiated by the peroxide resulted in the activation of the DNA repair enzyme poly-ADP polymerase. In parallel, a decrease of ATP was observed that was probably due to the inactivation of glyceraldehyde-3-dehydrogenase leading to inhibition of the glycolytic pathway. In addition, mitochondria became fragmented (76). Minutes following the addition of hydrogen peroxide, free intracellular calcium started to increase. Finally actin polymerization occurred, which was parallel to the formation of blebs in the plasma membrane (77). This led to enhanced plasma membrane permeability and to cell death.

Our finding that glucose-starved cells became much more susceptible to killing by combination: of hydrogen peroxide and SLS but not by hydrogen peroxide alone (41) also suggests that impairment of cellular metabolism by depriving them of energy sources might, however, not be sufficient to render the cells more susceptible to oxidants alone and that additional injuries are 
needed to destroy the cell membrane. It is noteworthy, however, that glucosestarved cells were capable of scavenging the same amounts of hydrogen peroxide as untreated cells (to be published). This indicates that the enhanced susceptibility of glucose-starved cells to combinations of SLS and hydrogen peroxide was not due to the depletion of catalase or perhaps of glutathione peroxidase, but might be due to the amplification by SLS of sublytic injuries induced by hydrogen peroxide. However, the short experiments performed might not represent the in vivo events that take place in inflammation under the effect of antimetabolites. It is also not known how the metabolic changes induced by hydrogen peroxide are related to the enhanced membrane damage obtained by membrane-active agents. To explain why the micromolar amounts of hydrogen peroxide employed in the current study failed to induce a rapid cytocidal effect (a 2-h assay), we have to compare this model with that which tested the effect of activated neutrophils on fibrosarcoma cells (72). We found that unless the mixtures of endothelial cells and PMNs were treated with sodium azide to inhibit catalase, no substantial killing of the targets took place. This suggests that the antioxidant systems of the cells acted as effective scavengers of hydrogen peroxide $(72,78)$. The PMNs, however, very effectively destroyed the cell monolayer and detached the cells presumably by secreting proteinases (72) (see Figure 6). This effect, however, was inhibited by adding proteinase inhibitors. Activated PMNs might thus enhance the spreading of tumor cells but fail to kill them (72). The sources of hydrogen peroxide in our in vitro model, which acted in concert with membrane-active agents to kill targets, might be GO, xanthine, and xanthine oxidase, or paraquat (Figures $7 \mathrm{~A}, 8$ ). The latter two agents are known to generate superoxide and hydrogen peroxide. Since, however, cell killing by mixtures of the hydrogen peroxide-generating systems with membrane-active agents was not inhibited either by SOD or by deferoxamine, but was markedly depressed by catalase, DMTU, or by $\mathrm{Mn}^{2+}$ (hydrogen peroxide scavengers), it is suggested that the active oxidant involved was indeed hydrogen peroxide. Oxygen-derived species can also induce the generation of peroxidation products in the plasma membranes (reviewed in 79). The altered membrane lipids might then become more susceptible to the effect of sublytic concentrations of membrane-active agents. The vast literature on the role of lipid peroxidation in cellular injury is, however, beyond the scope of the present communication. How do membrane-active agents (phospholipases, microbial hemolysins, cationic proteins) augment cellular injury induced by sublytic concentrations of hydrogen peroxide? An extensive literature is available on the mechanisms by which phospholipases and microbial hemolysins injure red blood cells and kill nucleated cells $(80,81)$. Phosopholipases are known to selectively hydrolyse membrane phospholipids and to generate lysophosphatides ( $\mathrm{PLA}_{2}$ action) and other degradation products of phospholipids (PLC action), etc. The breakdown of the membrane, at distinct sites might be accompanied by enhanced membrane 
permeability, rendering the cell nonviable. Although it was claimed that $\mathrm{PLA}_{2}$ has only a limited capacity to hydrolyze membrane phospholipids in intact cells, but not to cause hemolysis of $\mathrm{RBC}(80,81)$, we have demonstrated that hemolysis by $\mathrm{PLA}_{2}$ can be very effective if serum albumin is added. It seems that as long as the enzymatically hydrolyzed fatty acid remains within the structure of the membrane the lysophosphatides generated cannot exert their lytic effect. On the other hand, BGM cells cannot be killed by $\mathrm{PLA}_{2}$ and albumin unless hydrogen peroxide is also present. Thus nucleated cells differ from $R B C$ in their higher resistance to phospholipases. However, $\mathrm{PLA}_{2}$ might injure the membrane sublethally, which could "prime" the membrane for an oxidant assault. Lysophosphatides, however, also differ in their ability to perturb membranes. While lysophosphatidylcholine, lysophosphatidylinositol, and lysophosphatidylglycerol were found by us tc be highly hemolytic for human RBC and also capable of priming neutrophils for enhanced superoxide generation (50), lysophosphatides, with polar head groups (lysophosphatidylserine, lysophosphatidylethanolamine) were nonhemolytic and nonstimulatory for superoxide generation by human PMNs (50). The reason for this paradoxical finding is not known. Thus a limited cleavage of membrane phospholipids might be important in cellular damage provided that other agents capable of interacting with membranes are also present.

The mechanisms by which lysis of targets is induced by SLS is also not fully known $(20,23,81)$. Since, however, hemolysis of RBC by this hemolysin was totally inhibited by lecithin (82), it seems that hemolysis by this toxin involves interaction with membrane phospholipids. SLS, however, does not possess phospholipase activity (20).

Our earlier findings (23) that rat beating heart cells in culture could be killed, in the absence of added peroxide, when streptococci possessing cellbound SLS were layered upon them suggests that either the close contact between the streptococci and the targets allowed a more efficient delivery (transfer) upon the cells of the actively synthesized hemolysin or that the streptococci generated hydrogen peroxide, which acted synergistically with the hemolysin to kill the cells in a manner similar to that described in Figure 1. The inclusion of hydrogen peroxide scavengers together with streptococci might shed light on this problem.

The mechanisms by which cationic polypeptides injure mammalian membranes is also not fully understood $(10,83-86)$. Naturally occurring polycations (histones, beta-lysins, leukocyte cationic proteins, defensins) have been shown to be highly microbicidal and cytotoxic for a variety of mammalian cells in vitro and in vivo, presumably by interacting with the cell membranes $(10,36-39$, 83-86). Certain bactericidal polycations also collaborated with hydrogen peroxide to kill targets $(36-39,84)$. This might be due to the capacity of polycations to induce cross-linking of anionic surface structures, to alter membrane fluidity, and to induce altered cellular permeability $(10,84)$, which might be markedly 
augmented by oxidants, as shown when mixtures of hydrogen peroxide with histone, chlorhexidine, or polymyxin B, all cationic in nature, were employed (40-42).

Polycations have also been found to enhance the adherence of streptococci possessing cell-bound hemolysin (SLS) upon endothelial cells, which markedly enhanced cell killing in collaboration with hydrogen peroxide (41). Leukocytederived polycations might also enhance the binding of nonactivated PMNs to cell surfaces in sites of inflammation (87), activate the oxidative burst (10), and thus enhance the delivery of oxidants and lysosomal hydrolases directly upon the targets.

Taken together, it might be speculated that under in vivo conditions the simultaneous release by activated leukocytes of a multiplicity of agonists (oxidants, phospholipases, proteinases, and cationic proteins) might act in concert to induce enhanced cell and tissue injury similar to that induced in the more simplified tissue culture cell models described. The presence of proteinase inhibitors in serum (55) and the availability of antioxidants in cells might, however, mitigate the toxic effects induced by the multiple synergistic interactions described. Nevertheless to further enhance the antiinflammatory effects of such inhibitors, it is suggested that cocktails comprised of (1) antioxidants (catalase, SOD, beta-carotene, DMTU, $\mathrm{Mn}^{2+}$, and synthetic inhibitors of myeloperoxidase) (reviewed in Ref. 55), (2) both natural and recombinant proteinase inhibitors (55), (3) putative inhibitors of phospholipases $A_{2}$ and $C$, and (4) anionic polyelectrolytes to neutralize polycations be concocted.

Preliminary experiments have shown (41) that a cocktail of agonists comprised of GO-generated hydrogen peroxide, histone, PLC, lysolecithin, and trypsin, which acted as a "superkiller" of endothelial cells, could not be totally neutralized unless a cocktail of inhibitors comprised of catalase, heparin, chloroquine, phosphatidylserine, soybean trypsin inhibitor, and $50 \%$ fetal calf serum were present in the reaction mixtures. This suggests that such cocktails might perhaps also be effective in in vivo models yet to be constructed.

The introduction of novel and more potent forms of scavengers of oxygenderived species such as PEG-catalase and PEG-SOD has been reported (for reviews see 88-90). Catalase and SOD that had been cationized by the carbodiimide method proved beneficial against chronic erosive arthritis in rats (91) and the cationization of catalse by complexing with poly-L-histidine (92) also proved highly protective against oxidant cell killing in in vitro models. The employment of dimethylthiourea and thiourea ameliorated lung injury due to oxidants (71), and mixtures of glycine and divalent manganese proved beneficial for the protection of rat lungs against oxidant stress generated by glucose oxidase (70). Thus, these novel agents might also be added to the inhibitory cocktails, for in vivo treatments.

The novel concept of the role played by multiple synergistic interactions 
among agonists and their role in pathology might pave the way for a better treatment of inflammatory processes and their sequeallae.

The recent findings on the role played by cytokines $(16,93,94)$ as modulators of inflammation and the ability of certain cytokines not only to interact with one another (95) but to collaborate, in a synergistic manner, with oxidants (95-98) and with microbial toxins (98) to enhance cellular damage, open vistas and challenges for new approaches to a better understanding of the complexity of host and parasite interrelationships.

Finally, the striking similarities between the pathogenetic mechanisms of activated leukocytes and of group A streptococci and, perhaps, also of Clostridia, suggest that much can still be learned from toxigenic prokaroytes about how tissues are invaded and are eventually destroyed. The development of effective serotherapy against toxigenic microorganisms might also lead to the employment of effective measures against the deleterious effects of leukocyte enzymes. From the evolutionary point of view it perhaps might be justified to consider toxigenic microorganisms as the forefathers of "modern" leukocytes.

Acknowledgments-Supported by a research grant from Dr. S. M. Robbins, Cleveland, Ohio, and by grants HL-31963 and GM.29507 from the U.S. Public Health Service.

\section{REFERENCES}

1. SCOTland, S. M. 1988. Toxins. J. Appl. Bacteriol. Symp. Suppl. 1095-1295.

2. Bietschel, E. Th., L. Brade, U. Schade, U. Seydel, U. Zahringer, S. Kusumoto, and H. BRADE. 1988. Bacterial endotoxins: Properties and structure of biologically active domains. In Surface Structures of Microorganisms and their Interactions with the Mammalian Host. E. Schrinner, M. H. Richmond, G. Seibert, and U. Schwartz, editors. VCH Verlagsgesellschaft, Weinheim, Germany. 1-44.

3. BAYSON, K. F., and J. CoHEN. 1990. Bacterial endotoxins and current concept in the diagnosis and treatment of endotoxemia. J. Med. Microbiol. 31:73-83.

4. Diran, J. E. 1992. Biological effects of endotoxins. Gut-derived infectious toxic shock (GITS). Curr. Stud. Hematol. Blood Transfus. 59:66-99.

5. Holder, I. A. (editor). 1985. Bacterial Enzymes and Virulence. CRC Press, Boca Raton, Florida.

6. Ginsburg, I., and M. N. Sela, 1976. The role of leukocyte and their hydrolases in the persistence, degradation and transport of bacterial constituents in tissues: Relation to chronic inflammatory process in staphylococcal, streptococcal and mycobacterial infections and in chronic periodontal disease. Crit. Rev. Microbiol. 4:249-332.

7. GinsBurg, I. 1979. The: role of lysosomal factors of leukocytes in the biodegradation and storage of microbial constituents in infectious granulomas. In Lysosomes in Biology and Pathology, Vol. 6. J. Dingle editor. North Holland Publication, Amsterdam. 327-406.

8. MoRGAN, B. P. 1989. Complement membrane attack on nucleated cells: Resistance, recovery and non-lethal effects. Biochem. J. 264:1-15.

9. Henson, P. M., and R. B. Johnson. 1987. Tissue injury in inflammation, oxidants, proteinases and cationic proteins. J. Clin. Invest. 79:669-674. 
10. GINSBURG, I. 1987. Cationic polyelectrolytes: A new look at their possible roles as opsonins, as stimulators of the respiratory burst in leukocytes in bacteriolysis and as modulators of immune complex disease. Inflammation 11:489-515.

11. Klebanoff, S. F. 1988. Phagocytic cells: Products of oxygen metabolism. In Inflammation Basic Principles and Clinical Correlates. J. I. Gallin, I. M. Goldstein, and R. Snyderman editors. Raven Press, New York. 391-444.

12. HaLliwell, B. 1989. Free radicals, reactive oxygen species and human disease: A critical evaluation with special reference to artherosclerosis. Br. J. Exp. Pathol. 70:737-757.

13. WARD, P. A., and J. VARANI. 1990. Mechanisms of neutrophil-mediated killing of endothelial cells. J. Leukocyte Biol. 48:97-102.

14. Farber, J. L., M. E. Kyle, and J. B. Coleman. 1990. Mechanisms of cell injury by active oxygen species. Lab. Invest. 62:670-679.

15. Gallin, J. I., I. M. Goldstein, and R. SnYderman, editors. 1988. Inflammation, Basic Principles and Clinical Correlates. Raven Press New York.

16. MizeL, S. B. 1989. The interleukins. FASEB 3:2379-2388.

17. GinsBurg, I. 1972. Mechanisms of cell and tissue injury induced by group A streptococci: Relation to poststreptococcal sequelae. Parts I and II. J. Infect. Dis. 126:294-340; 419-456.

18. GinsBuRg, I. 1985. Streptococcal enzymes and virulence. In Bacterial Enzymes and Virulence. I. A. Holder, editor. CRC Press, Boca Raton, Florida. 121-144.

19. Wexler, D. E., D. E. Chenoweth, and P. P. Cleary. 1985. Mechanism of action of the group A streptococcal C5a inactivator. Proc. Natl. Acad. Sci. U.S.A. 82:8144-8148.

20. Ginsburg, I. 1979. Streptolysin S. In Microbial Toxins. T. C. Montie, S. Kadis, S. Ajl, editors. Academic Press, New York. 99-171.

21. Alouf, J. E. 1980. Streptococcal toxins (streptolysin O, streptolysin S, erythrogenic toxin). Pharmacol. Ther. 11:661-717.

22. GinsBurG, I., and N. GRossowicz. 1960. Effect of streptococcal hemolysins on Ehrlich ascites tumor cells. J. Pathol. Bacteriol. 80:111-119.

23. Marcus, Z., M. A. Davies, and I. GinsBurg. 1965. Oxygen-stable hemolysins of group A streptococci. V. Effect on rat heart and kidney cells grown in tissue culture. Exp. Mol. Pathol. 5:93-107.

24. OfEK, I., S. BERGNer-RABinOWITZ, and I. GinSBurg. 1972. Oxygen-stable hemolysins of group A streptococci. VIII. Leukotoxic and antiphagocytic effects of streptolysin S and O. Infect. Immun. 6:459-464.

25. WICKEN, A. J., and K. W. KNOX. 1978. Lipoteichoic acids: A new class of bacterial antigens. Science 187:1161-1167.

26. OfeK, I., E. F. Beachy, W. JefFerson, and G. L. Cambell. 1975. Cell membrane binding properties of group A streptococcal lipoteichoic acid. J. Exp. Med. 141:990-1003.

27. GinsBurg, I., and T. N. HARRIS. 1965. Oxygen-stable hemolysins of group A streptococci. IV. Studies on the mechanism of lysis by cell-bound hemolysin of red blood cells and Ehrlich ascites tumor cells. J. Exp. Med. 121:647-656.

28. Yammamoto, A., H. Usami, M. Nagamuta, Y. Sugawara, S. Hamada, T. Yamammoto, K. Kato, S. Kokeguchi, and S. Kotani. 1985. The use of lipoteichoic acid (LTA) from streptococcus pyogenes to induce a serum factor causing tumor necrosis. Br. J. Cancer 51:739742.

29. FIEDEL, B. A., and R. W. JACKSON. 1981. Complement activation by streptococcal LTA. In Chemistry and Biological Activities of Bacterial Surface Amphiphiles. G. D. Shockman, and A. Wicken, editors. Academic Press, New York. 305-314.

30. ALBELDA, S. M., and C. A. BuCK. 1990. Intergrins and other cell adhesion molecules. FASEB J. 4:2868-2880. 
31. Patarroyo, M. 1991. Leukocyte adhesion in host defense and tissue injury. Clin. Immunol. Immunopathol. 60:333-348.

32. GinSBURG, I. 1959. Action of streptococcal hemolysins and proteolytic enzymes on Ehrlich ascites tumor cells. Bri. J. Exp. Pathol. 40:417-423.

33. GINSBURG, I., and N. RAM. 1963. Effect of antibodies and plasmin on Ehrlich ascites tumor Cells. Nature 185:328-330.

34. Dishon, T., R. Finkel, z. Marcus, and I. Ginsburg. 1967. Cell sensitizing products of streptococci. Immunology 13:555-564.

35. Lopatin, D., and R. E. Kessler. 1985. Pretreatment with lipoteichoic acid sensitizes target cells to antibody-dependen: cellular cytotoxicity in the presence of anti-lipoteichoic antibodies. Infect. Immun. 48:638-643.

36. Adams, D. O., W. J. Johnson, E. Frorito, and C. F. Nathan. 1981. Hydrogen peroxide and cytolytic factor can interact synergistically in effecting cytolysis of neoplastic targets. $J$. Immunol. 127:1973-1977.

37. Yazdanbakhsh, M., P. C. Tai, C. J. F. Sory, G. J. Gleich, and D. Roos. 1987. Synergism between eosinophil cationic protein and oxygen metabolites in killing of schistosomula of Schistosoma mansoni. J. Immunol. 138:3443-3447.

38. Agosti, J. M., L. C. Altman, G. H. Ayars, D. A. Loegering, and G. J. Gleich. 1987. The injurous effect of eosinophil peroxidase, hydrogen peroxide and halide on pneumocytes in vitro. J. Allergy Clin. Immunol. 79:496-504.

39. Lichtenstein, A. K., T. GANZ, M. E. Selsted, and R. I. Lehrer. 1988. Synergistic cytolysis mediated by hydrogen peroxide combined with peptide defensin. Cell Immunol. 114:104-116.

40. Ginsburg, I., D. F. Gibb3, L. Schugan, K. J. Johnson, U. S. Ryan, P. A. Ward, and J. VARANI. 1989. Vascular endothelial cell killing by combinations of membrane-active agents and hydrogen peroxide. Free Rad. Biol. Med. 7:369-375.

41. Ginsburg, I., R. Mitra, I), F. GibBs, J. Varani, and R. Kohen. 1992. Killing and arachidonic acid release from endothelial cells: Synergy among oxidants, membrane-damaging agents and proteinases. Inflamm. Pharmacol. (in press).

42. Ginsburg, I., T. E. Bramanti, J. L. Ebersole, and S. C. Holt. 1992. Interaction of Porphyromonas gingivalis with human erythrocytes and epithelial cells: Role of the cell bound hemolysin and phospholipids in cell lysis (submitted).

43. Rodell, T. C., J. C. Cheronis, C. L. Ohnemus, D. J. Piermattei, and J. E. Repine. 1987. Xanthine oxidase mediates elastase-induced injury to isolated lungs and endothelium. Am. $J$. Physiol. 63:2159-2163.

44. Pontremoli, E., E. Melloni, M. Michetti, O. Sacco, B. Sparataore, F. Salamino, G. DAMIANI, and B. L. HORECKER. 1986. Cytolytic effects of neutrophils: Role of membranebound neutral proteinase. Proc. Natl. Acad. Sci. U.S.A. 83:1685-1689.

45. Varani, J., I. Ginsburg, L. Schuger, D. C. Gibbs, J. Bromberg, K. J. Johnson, U. S. RYAN, and P. A. WARD. 1989. Endothelial cell killing by neutrophils. Synergistic interaction of oxygen products and poteases. Am. J. Pathol. 135:435-438.

46. Ginsburg, I., R. Borinski, M. Lahay, Y. Matzner, I. Elliasson, P. Christensen, and D. MALAMUD. 1985. Poly-L-arginine and $N$-formylated chemotactic peptides act synergistically with lectins and calcium ionophore to induce intense chemiluminescence and superoxide production by human blood leukocytes. Inflammation 8:1-26.

47. MCPhaIL, L. C., P. M. Henson, and R. B. Johnston. Respiratory burst in human neutrophils. Evidence for multiple mechanism of activation. J. Clin. Invest. 67:710-716.

48. FOREHAND, J. R., J. S. BOMALSKI, and R. B. JOHNSTON. 1991. Mechanisms of lipopolysaccharide priming for enhanced respiratory burst activity in human neutrophils. In New Aspects 
of Human Polymorphonuclear Leukocytes. W. H. Horl and P. J. Schollmeyer, editors. Plenum Press, New York. 65-73.

49. Engleberger, W., K. Bitter-Suerman, and U. Hadding. 1987. Influence of lysophospholipids and PAF on the oxidative burst in PMNL. Int. J. Immunopharmacol. 9:275-282.

50. GinsburG, I., P. A. WARD, and J. VARANI. 1989. Lysophosphatides enhance superoxide responses in stimulated human neutrophils. Inflammation 13:163-174.

51. Ginsburg, I., S. E. G. Fligiel, P. A. Ward, and J. Varani. 1989. Lipoteichoic acid-antilipoteichoic acid complexes induce superoxide generation by human neutrophils. Inflammation 12:525-545.

52. Halliwell, B., J. R. Hoult, and D. R. Blake. 1990. Oxidants, inflammation and antiinflammatory drugs. FASEB J. 2:2867-2873.

53. Rubayny, G. M. 1988. Vascular effects of oxygen-derived free radicals. Free Rad. Biol. Med. 4:107-120.

54. JAMISON, D. 1989. Oxygen toxicity and reactive oxygen metabolites in mammals. Free Rad. Biol. Med. 7:87-108.

55. WeISS, S. J. 1989. Tissue destruction by neutrophils. N. Engl. J. Med. 320:365-376.

56. SiBILLE, I., and H. Y. ReYNolds. 1990. Macrophages and polymorphonuclear neutrophils in lung defense and injury. Am. Rev. Respir. Dis. 141:471-501.

57. Saltman, P. 1989. Oxidative stress: A radical view. Semin. Hematol. 26:249-256.

58. Jesitis, A. J., M. T. Quinn, G. Mukherjee, P. A. Ward, and E. A. Dratz. 1991. Death by oxygen: Radical views. New Biol. 3:651-655.

59. WARD, P. A. 1991. Mechanisms of endothelial cell injury. J. Lab. Clin. Med. 118:421-426.

60. Till, G. O., H. P. FrIEDL, and P. A. WARD. 1991. Lung injury and complement activation: Role of neutrophils and xanthine oxidase. Free Rad. Biol. Med. 10:379-386.

61. MCCORD, J. M. 1988. Free radicals in myocardial ischemia: Overview and outlook. Free Rad. Biol. Med. 4:9-14.

62. Luccesi, B. R., S. W. Werns, and J. C. Fantone. 1989. The role of neutrophil and free radicals in ischemic myocardial injury. J. Mol. Cell. Cardiol. 21:1241-1251.

63. PIPER, H. M. editor. 1990. Pathophysiology of Severe Ischemic Myocardial Injury. Kluwer Academic Publisher, Dordrecht.

64. Van Der Vus, G. J., M. Van Blisen, T. Sonderkamp, and R. S. Reneman. 1990. Hydrolysis of phospholipids and cellular integrity. In Pathophysiology of Severe Ischemic Myocardial Injury. H. M. Piper, editor. Kluwer Academic Publishers, Dordrecht. 167-193.

65. Mullane, K. M., and C. W. SMrTh. 1990. The role of leukocytes in ischemic damage, reperfusion injury and repair of the myocardium. In Pathophysiology of Severe Ischemic Myocardial Injury. H. M. Piper, editor. Kluwer Academic Publisher, Dordrecht. 239-267.

66. Yagev, S., M. Heller, and A. Pinson. 1984. Changes in cytoplasmic and lysosomal enzyme activities in cultured heart cells: The relationship to cell differentiation and cell population in culture. In Vitro 20:893-898.

67. Solar, S., W. Solar, N. Gestoff, J. Holcman, and K. Sehested. 1982. Pulse-radiolysis of methyl viologen in aqueous solutions. J. Chem. Soc. Faraday Trans. 78:2467-2477.

68. Ginsburg, I., R. Borinski, M. Sadovnic, Y. Eilam, and K. Rainsford. 1987. Poly-L-histidine. A potent stimulator of superoxide generation by human blood leukocytes. Inflammation 11:253-277.

69. Thurman, R. G., H. G. Leyland, and R. Scoltz. 1972. Hepatic microsomal ethanol oxidation hydrogen peroxide formation and the role of catalase. Eur. J. Biochem. 25:42-430.

70. Varani, J., I. Ginsburg, D. F. Gibbs, P. S. Mukhpadhyay, C. Sulavik, K. J. Johnson, Y. M. WeINBERG, U. S. RYAN, and P. A. WARD. 1991. Hydrogen peroxide-induced cell and tissue injury: Protective effects of $\mathrm{Mn}^{2+}$. Inflammation 15:291-301.

71. Toth, K. M., J. M. Harlan, E. M. Berger, N. B. Parker, and J. E. Repinne. 1989. 
Dimethylthiourea prevents hydrogen peroxide mediated damage to bovine pulmonary artery endothelial cells and disaprears in the process. Free Rad. Biol. Med. 6:457-466.

72. GinsBurG, I., D. F. GibBS, and J. VARANI. 1989. Interaction of mammalian cells with polymorphonuclear leukocytes: Relative sensitivity to monolayer disnuption and killing. Inflammation 13:529-542.

73. Schraufstatter, I. U., P. A. Hyslop, J. Jackson, and C. C. Cochrane. 1986. Mechanisms of oxidant injury of cells. $I z \mathrm{H}$. Movat, editor. Leukocyte Migration and Its Sequelae. Satellite Symposium 6th International Congress on Immunology, 1150-1160.

74. LiCHTENSTEIN, A. 1989. Machanisms of neutrophil-mediated oxidative and non-oxidative tumor lysis. In New Horizons of Tumor Immunotherapy. M. Torisu and Y. Yoshida, editors. Elsvier Science Publishers, Amste:dam. 79-100.

75. SPRAG, R, G. 1991. DNA, strand break formation following exposure of bovine pulmonary artery and aortic endothelial cells to reactive oxygen products. Am. J. Respir. Cell Biol. 4:4-10.

76. Mehrotra, S., P. MakKar, and P. N. Viswanathan. 1991. Mitochondrial damage by oxygen species in vitro, Free Rad. Biol. Med, 10:277-283.

77. Scitt, J. A., A. J. Fischian, C. J. Homcy, J. T. Fallon, B. A. Khaw, C. A. Peto, and C. A. RABITO. 1990. Morphological and functional correlates of plasma membrane injury during oxidant exposure. Free Rad. Biol. Med. 6:361-367.

78. Simon, R. H., P. D. DEHA.RT, and D. M. NAdEAU. 1989. Resistance of rat pulmonary alveolar eothelial cells to neutrophil and oxidant-induced injury. Am. J. Respir. Cell Mol. Biol. 1:221229.

79. JANERO, D. R. 1990. Malonaldehyde and thiobarbituric acid-reactivity as diagnostic indices of lipid peroxidation and peroxidative tissue injury. Free Rad. Biol. Med. 9:515-540.

80. Condrea, C. 1979. Snake venoms. Handb. Exp. Pharmacol. 52:448-479.

81. BERNhEImER, A. W., and B. RUDY. 1986. Interactions between membranes and cytolytic peptides. Biochim. Biophys. Acta 864:1213-141.

82. Elias, N., M. Heller, and I. GinsBurg. 1966. Binding of streptolysin S to red cell ghosts and ghost lipids. Isr. J. Mred. Sci. 2:302-309.

83. Lambert, P. P., P. Bergmann, and R. Beauwens editors. 1983. The Pathogenicity of Cationic Proteins. Tavern Press, New York.

84. Ginsburg, I. 1989. Cationic polyelectrolytes: Potent opsonic agents which activate the respiratory burst in leukocytes. Free Rad. Res. Commun. 8:11-26.

85. SpITZNAGEL, J. K. 1984. Non-oxidative antimicrobial reactions of leukocytes. Contemp. Top. Immunobiol. 14:383-343.

86. ElSBACH, P., and J. Welss. Phagocytic cells: Oxygen-independent antimicrobial systems. In Inflammation, Basic Principles and Clinical Correlates. J. I. Gallin, I. M. Goldstein, and R. Snyderman, editors. Raven Press, New York.

87. Oseas, R. S., J. Allen, F. H. YANG, R. L. Baehner, and L. A. Boxer. 1981. Rabbit cationic protein enhances leukocytes adhesiveness. Immunology 33:523-526.

88. Flohe, L. 1988. Superoxide dismutase for therapeutic use: Clinical experience dead ends and hopes. Mol. Cell. Biochein. 84:123-131.

89. Greenwald, R. A. 1990. Superoxide dismutase and catalase as therapeutic agents for human disease. A critical review. Free Rad. Biol. Med. 8:201-209.

90. CRoss, A. R. 1990. Inhibitors of leukocyte superoxide generating oxidase: Mechanisms of action and methods for their evaluation. Free Rad. Biol. Med. 8:71-93.

91. Schwalwijk, J., W. B. Van Den Berg, L. Van Den Futte, L. A. B. Joosten, and L. Van DEN BERSSELAAR. 1985. Cationization of catalase, peroxidase and superoxide dismutase. Effect of improved intraarticular retention on experimental arthritis in mice. J. Clin. Invest. 76:198205. 
92. GIBBS, D. F., J. VARANI, and I. GINSBURG. 1989. Formation and use of poly-L-histidine catalase complexes: Protection of cells from hydrogen peroxide-mediated injury. Inflammation 13:465474.

93. Tracey, K. J. and A. Cerami. 1990. Metabolic responses to cachectin/TNF: A brief review. Ann. Acad. Sci. 587:325-331.

94. Cerami, A. 1992. Inflammatory cytokines. Clin. Immunol. Immunopathol. 62:S3-S10.

95. Talmadge, J. E., O. Bowersox, H. Tribble, S. de Lee, H. M. Shepard, and D. Liggit. 1987. Toxicity of tumor nectrosis factor is synergistic with gamma interferon and can be reduced with cycloogygenase inhibitors. Am. J. Pathol. 128:410-414.

96. Warren, J. S., S. L. Kunkel, T. W. Cunningham, K. L. Johnson, and P. A. Ward. 1988. Macrophage-derived cytokines amplify immune complex-triggered $\mathrm{O}_{2}^{-}$responses by rat alveolar macrophages. Am. J. Pathol. 130:489-495.

97. Varani, J., M. J. Bendelow, D. E. Sealey, S. L. Kunkel, D. E. Gannon, U. S. Ryan, and P. A. WARD. 1988. Tumor necrosis factor enhances susceptibility of vascular endothelial cells to neutrophil-mediated killing. Lab. Invest. 59:292-295.

98. Slungaard, A., G. M. Vercelloti, G. Walker, R. D. Nelson, and H. S. Jacob. 1990. Tumor necrosis factor/cachectin stimulates eosiniphil oxidant production and toxicity toward human endothelium. J. Exp. Med. 171:2025-2041. 